\title{
Psoriatic dactylitis: Koebner phenomenon of the pulleys - comment on "Ultrasound assessment in psoriatic arthritis (PsA) and psoriasis vulgaris (non-PsA): which sites are most commonly involved and what features are more important in PsA?"
}

\author{
Rana Terlemez^, Deniz Palamar, Tugce Ozekli Misirlioglu, Kenan Akgun \\ Department of Physical Medicine and Rehabilitation, Cerrahpasa School of Medicine, Istanbul University-Cerrahpasa, Istanbul, Turkey \\ Correspondence to: Rana Terlemez, MD. Nafiz Gurman Street, Department of Physical Medicine and Rehabilitation, Cerrahpasa School of Medicine, \\ Istanbul University-Cerrahpasa, Fatih, Istanbul 34098, Turkey. Email: ranakaynar@hotmail.com.
}

Response to: Tang Y, Cheng S, Yang Y, Xiang X, Wang L, Zhang L, Qiu L. Ultrasound assessment in psoriatic arthritis (PsA) and psoriasis vulgaris (non-PsA): which sites are most commonly involved and what features are more important in PsA? Quant Imaging Med Surg 2020;10:86-95.

Submitted Mar 11, 2021. Accepted for publication May 21, 2021.

doi: 10.21037/qims-21-275

View this article at: https://dx.doi.org/10.21037/qims-21-275

We have taken interest in the recently published article entitled "Ultrasound assessment in psoriatic arthritis (PsA) and psoriasis vulgaris (non-PsA): which sites are most commonly involved and what features are more important in PsA?" by Tang et al. (1). They provided a comprehensive review of the role of ultrasound (US) in PsA. They emphasized the importance of assessing joints, tendons, enthesis and bursae. We congratulate the authors for their effort in increasing the awareness the use of US in PsA. However, we also like to underline the importance of US examination of pulleys in patients with PsA.

A 23-year-old woman presented to our clinic with pain and swelling in the right index finger of her right hand for 2 weeks. Prior to her visit, she had spent months writing for long hours with her right hand. Her medical history revealed that she had psoriasis for a year which was well controlled with local medical agents. Upon physical examination, she had local tenderness and swelling in her right index finger (Figure 1). Further inspection revealed minimal psoriatic plaques on her scalp. All laboratory assessments, including acute phase reactants, were normal. Ultrasonographic examination revealed flexor

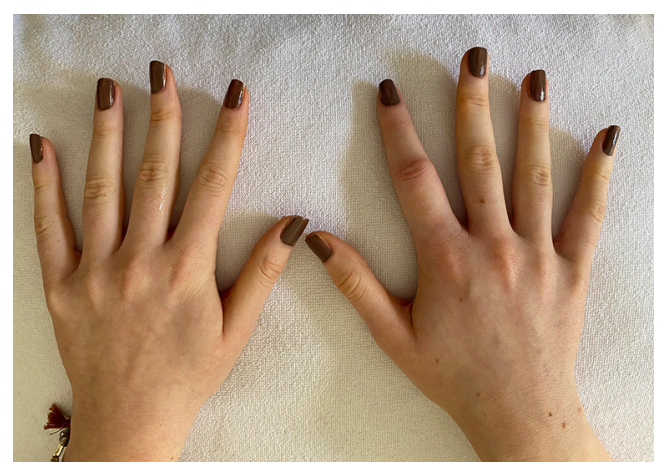

Figure 1 Soft tissue swelling in the index finger of the right hand.

tenosynovitis and diffuse isoechoic thickening of the extratendinous soft tissues around the flexor tendon (pseudotenosynovitis). Axial scan of the finger showed increased thickness of the pulleys and intra-pulley power Doppler signals, especially in the A2 pulley (Figure 2). We considered the diagnosis of psoriatic dactylitis and started the patient on methotrexate at a dosage of $10 \mathrm{mg} / \mathrm{week}$. All procedures performed in studies involving human

$\wedge$ ORCID: 0000-0002-8202-0931. 


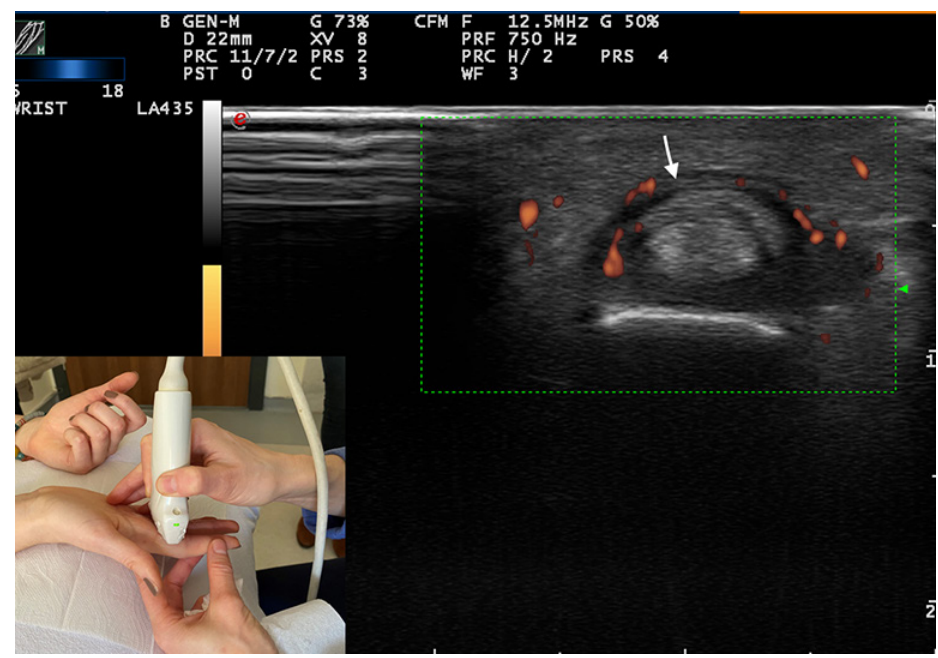

Figure 2 Axial scan of the increased thickness of A2 pulley and intra-pulley power doppler signals. White arrow: A2 pulley.

participants were in accordance with the ethical standards of the institutional and/or national research committee(s) and with the Helsinki Declaration (as revised in 2013). Written informed consent was obtained from the patient.

Finger pulleys are annular and cruciform structures that hold the flexor tendons close to the phalanges and facilitate strong flexion of the digits. These avascular structures prevent the tendons from bow stringing and can withstand high physical stress during daily living activities. It is currently assumed that the inflammation may begin at pulleys which have a role of functional entheses in psoriatic dactylitis (2). Likewise, the exaggerated response to skin trauma known as Koebner phenomenon, excessive repair responses in the pulleys can be seen as "deep koebnerization" (3).

A recent study by Tinazzi et al. demonstrated the involvement of the pulleys in patients with active psoriatic dactylitis (4). In another study, they suggested using ultrasonographic evaluation of the pulleys to differentiate between rheumatoid arthritis and PsA, especially in the early phase of the disease (3). Our case study shows evidence of "deep Koebnerization" with increased thickness and power Doppler signals of the pulleys triggered by prolonged finger flexion during writing by hand. Detecting signs of physical stress at these sites may help in understanding the predisposing factors for dactylitis in patients with psoriasis.

\section{Acknowledgments}

Funding: None.

\section{Footnote}

Provenance and Peer Review: This article was a standard submission to the journal. The article has undergone external peer review.

Conflicts of Interest: All authors have completed the ICMJE uniform disclosure form (available at https://dx.doi. org/10.21037/qims-21-275). The authors have no conflicts of interest to declare.

Ethical Statement: The authors are accountable for all aspects of the work in ensuring that questions related to the accuracy or integrity of any part of the work are appropriately investigated and resolved. All procedures performed in studies involving human participants were in accordance with the ethical standards of the institutional and/or national research committee(s) and with the Helsinki Declaration (as revised in 2013). Written informed consent was obtained from the patient.

Open Access Statement: This is an Open Access article distributed in accordance with the Creative Commons Attribution-NonCommercial-NoDerivs 4.0 International License (CC BY-NC-ND 4.0), which permits the noncommercial replication and distribution of the article with the strict proviso that no changes or edits are made and the original work is properly cited (including links to both the formal publication through the relevant DOI and the license). See: https://creativecommons.org/licenses/by-nc-nd/4.0/. 


\section{References}

1. Tang Y, Cheng S, Yang Y, Xiang X, Wang L, Zhang L, Qiu L. Ultrasound assessment in psoriatic arthritis (PsA) and psoriasis vulgaris (non-PsA): which sites are most commonly involved and what features are more important in PsA? Quant Imaging Med Surg 2020;10:86-95.

2. Sapundzhieva T, Karalilova R, Batalov A. Hand ultrasound patterns in rheumatoid and psoriatic arthritis: the role of ultrasound in the differential diagnosis. Rheumatol Int

Cite this article as: Terlemez R, Palamar D, Misirlioglu TO, Akgun K. Psoriatic dactylitis: Koebner phenomenon of the pulleys-comment on "Ultrasound assessment in psoriatic arthritis (PsA) and psoriasis vulgaris (non-PsA): which sites are most commonly involved and what features are more important in PsA?”. Quant Imaging Med Surg 2021;11(11):4687-4689. doi: 10.21037/qims-21-275
2020;40:837-48.

3. Tinazzi I, McGonagle D, Aydin SZ, Chessa D, Marchetta A, Macchioni P. 'Deep Koebner' phenomenon of the flexor tendon-associated accessory pulleys as a novel factor in tenosynovitis and dactylitis in psoriatic arthritis. Ann Rheum Dis 2018;77:922-5.

4. Tinazzi I, McGonagle D, Macchioni P, Aydin SZ. Power Doppler enhancement of accessory pulleys confirming disease localization in psoriatic dactylitis. Rheumatology (Oxford) 2020;59:2030-4. 